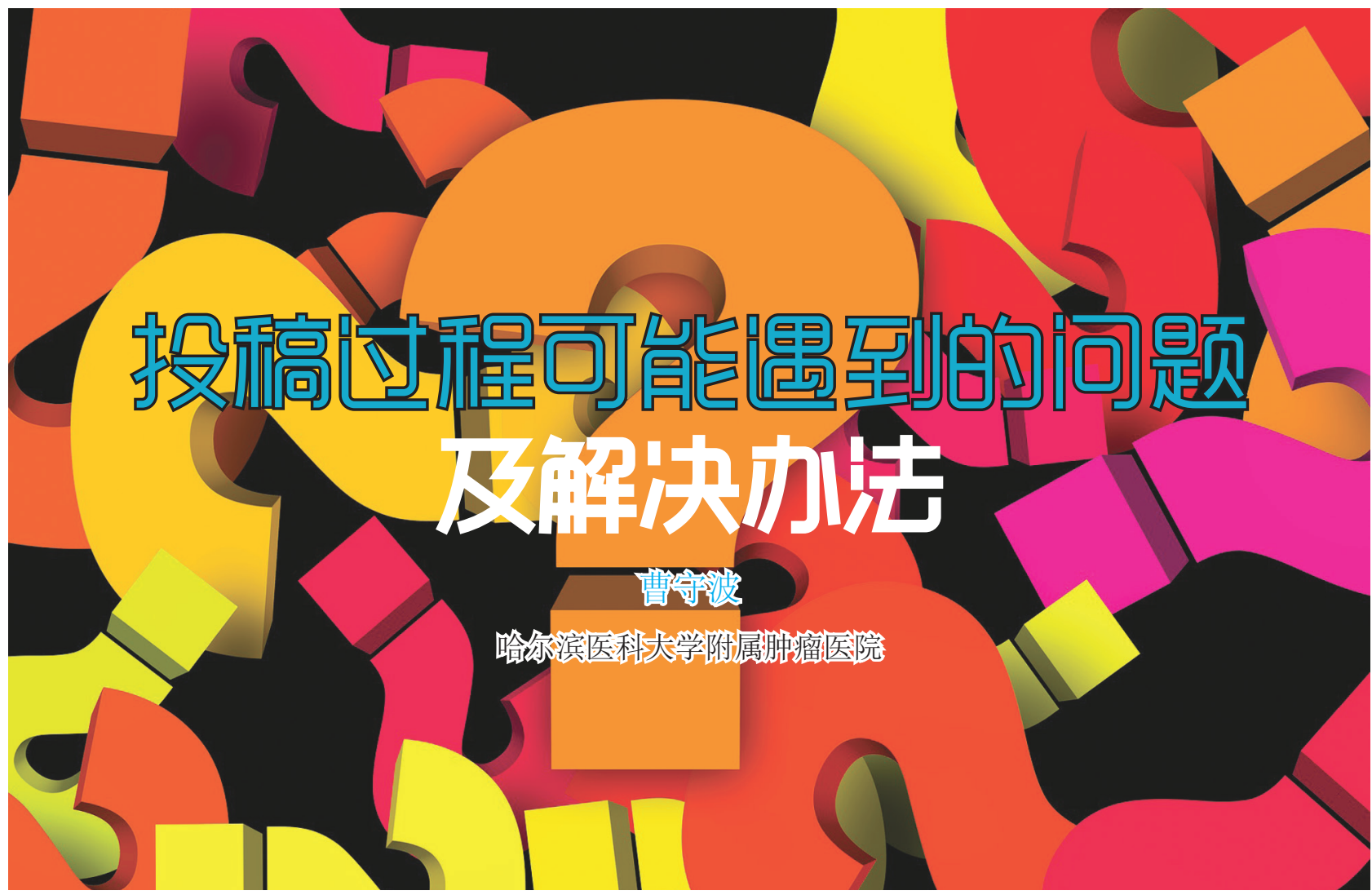

医学论文的发表对我们临床 医生的工作具有重要的指导意义, 而论文投稿是发表过程中不可或 缺的环节。对于论文投稿, 我们 尤为需要引起重视的是投稿须知 (instructions for authors), 对于 投稿须知, 必须精读、细读, 磨 刀不误砍柴工这一说法尤其适用 于投稿过程, 否则, 你可能会走 很多弯路, 费时费力。投稿是一 份繁琐的工作, 需要引起我们足 够的重视, 按照投稿须知的要求
来做, 就会相对容易些。否则, 你的很多前期工作都需要重新返 工, 费时费力。下面我以 Clinical Lung Cancer 杂志为例列举一下投 稿过程中可能遇到的问题及解决 方法。

\section{1. 文章内容和类型不在收} 稿范围内。这一点非常重要, 选 择杂志的时候一定要确保自己文 章的内容和类型在杂志的收录范 围, 否则, 不仅浪费了你大量的 投稿时间, 也给审稿人增加了额
外的负担。以下图为例, 杂志主 要接收肺癌领域的文章, 如果你 文章内容是关于乳腺癌的, 那就 相对文不符题了。至于文章类型 的问题, 如果杂志明确说明只接 收 original article 和 review, 而 你想投 case report, 这也是不合 适的。另外, 有些杂志是只接收 约稿的, 不接收自由投稿, 如果 你实在想投, 那投稿之前最好发 邮件问问编辑是否能考虑自由投 稿。

\title{
GUIDE FOR AUTHORS
}

\section{INTRODUCTION}

Clinical Lung Cancer is a peer-reviewed bimonthly journal that publishes original articles describing various aspects of clinical and translational research of lung cancer. Clinical Lung Cancer is devoted to articles on detection, diagnosis, prevention, and treatment of lung cancer. The main emphasis is on recent scientific developments in all areas related to lung cancer. Specific areas of interest include clinical research and mechanistic approaches; drug sensitivity and resistance; gene and antisense therapy; pathology, markers, and prognostic indicators; chemoprevention strategies; multimodality therapy; and integration of various approaches. 
2. 伦理和利益冲突声明。这 点很容易被忽略, 尤其是刚接触 投稿的时候，杂志社也会经常把
稿件返回给作者重新补这些内容, 所以我单独把它列出来。以下图 为例, 涉及人和动物的研究都要
符合伦理要求, 这点也要在文章 中指出来, 对于有利益冲突的, 也要说的详细一些。

\begin{abstract}
Editorial Policies and Practices
Human Subject Studies: It is the responsibility of the authors to assure that all clinical investigations detailed in manuscripts submitted to the journal are conducted in accordance with the Declaration of Helsinki and to document that these studies have been approved by the appropriate institutional human research committee. Identifying information within written descriptions, photographs or pedigrees should not be published. If such information is included as essential scientific information, the authors must submit written consent of patient or guardian to publish such photographs in the print and electronic versions of the journal.
\end{abstract}

\begin{abstract}
Animal Studies: It is the responsibility of the authors to assure that their experimental procedures are in compliance with the guiding principles in the "'Care and Use of Animals"'" (published each month in the Information for Authors of the American Journal of Physiology or available online at http://www.nap.edu/books/0309053773/html/) and to document that these studies were approved by the appropriate institutional animal care and oversight committee.

Declaration of interest

All authors must disclose any financial and personal relationships with other people or organizations that could inappropriately influence (bias) their work. Examples of potential conflicts of interest include employment, consultancies, stock ownership, honoraria, paid expert testimony, patent applications/ registrations, and grants or other funding. If there are no conflicts of interest then please state this: 'Conflicts of interest: none'. More information.
\end{abstract}

Financial interests should be disclosed to the Editor-in-Chief in the cover letter and on a separate conflict of interest page in the manuscript.

3. 文章是否为开放获取。开 放获取已经成为目前杂志的主流， 以下图为例，如果你选择开放获 取，那么你需要支付文章开放获
取出版模式的费用，否则，你不 用支付这项费用。对于课题经费 不是很充足的作者来说，可以选 择后者。不过有很多杂志直接是
开放获取的，这样你直接付给杂 志社相应的费用就可以了, 不过这 一步多数是在文章接受后才会选 择的。

\title{
Open access
}

This journal offers authors a choice in publishing their research:

\section{Open access}

- Articles are freely available to both subscribers and the wider public with permitted reuse.

- An open access publication fee is payable by authors or on their behalf, e.g. by their research funder or institution.

- Articles are made available to subscribers as well as developing countries and patient groups through

our universal access programs.

- No open access publication fee payable by authors.

\section{4. 文章正文缺少杂志要求} 的信息或不符合杂志的要求。这 一点一定要按部就班的看投稿须 知的 preparation 部分, 它会详 细地记录从 title page, abstract, keywords, introduction, methods and materials, results, discussion, acknowledgements 到 conflict of interest 的内容, 你只 要按照杂志要求来写, 一般都没 有问题。另外, 多数杂志会要求 cover letter, cover letter 要注明
文章不存在一稿多投和利益冲突 问题，所有作者都同意文章的发 表, 以及文章的重要研究发现、 通讯作者的联系方式等。

\section{5. 参考文献格式与杂志要} 求不吻合。这个问题是可以通过参 考文献管理软件来实现的。如果 你会用软件的话, 在软件里选择 合适的杂志就可以了, 如果杂志 不在目录内, 你也可以自己设置 参考文献格式, 在这里就不一一 赘述了。
6. 图表不符合杂志要求。 这点是最常遇到的。图表对文章 起着点缀的作用, 因此图表的制 作一定要符合杂志要求, 否则, 返工是很折磨人的。此外还涉及 到彩图的发表问题等, 因为彩图 是收费的, 如果选择为黑白出版, 那就不需要付彩图费了。对于图 片要求, TIFF 格式、600dpi 以上 应该可以满足大多数杂志的要求, 不过具体还得看杂志。 


\begin{abstract}
You are urged to visit this site; some excerpts from the detailed information are given here. Formats

If your electronic artwork is created in a Microsoft Office application (Word, PowerPoint, Excel) then please supply 'as is' in the native document format.

Regardless of the application used other than Microsoft Office, when your electronic artwork is finalized, please 'Save as' or convert the images to one of the following formats (note the resolution requirements for line drawings, halftones, and line/halftone combinations given below):

EPS (or PDF): Vector drawings, embed all used fonts.

TIFF (or JPEG): Color or grayscale photographs (halftones), keep to a minimum of $300 \mathrm{dpi}$.

TIFF (or JPEG): Bitmapped (pure black \& white pixels) line drawings, keep to a minimum of $1000 \mathrm{dpi}$. TIFF (or JPEG): Combinations bitmapped line/half-tone (color or grayscale), keep to a minimum of $500 \mathrm{dpi}$.
\end{abstract}

Tables

Please submit tables as editable text and not as images. Tables can be placed either next to the relevant text in the article, or on separate page(s) at the end. Number tables consecutively in accordance with their appearance in the text and place any table notes below the table body. Be sparing in the use of tables and ensure that the data presented in them do not duplicate results described elsewhere in the article. Please avoid using vertical rules and shading in table cells.

一篇文章的完成无外乎需要 cover letter, manuscript 正文, tables, figures 和 figure legends 这几 部分, 所以这也是投稿须知中需要 着重看的地方。另外, 有些杂志会 希望推荐审稿人, 所以你还得选择
几个推荐的审稿人, 把他们的姓名、 单位和邮箱单独建一个文档列出 来, 方便投稿用。对于有目的期刊 杂志的, 你可以先参考一下杂志的 投稿须知, 这样做起事来更加得 心应手, 会省去很多不必要的工作。
比如说, 杂志要求限制文稿的字数 在 3000 字, 你就不必要洋洋酒酒 写很多，能一句话解释清楚地问 题尽量简略。希望能够引起大家对 投稿须知的重视, 在投稿过程中 用最省力的方式做更多的工作。

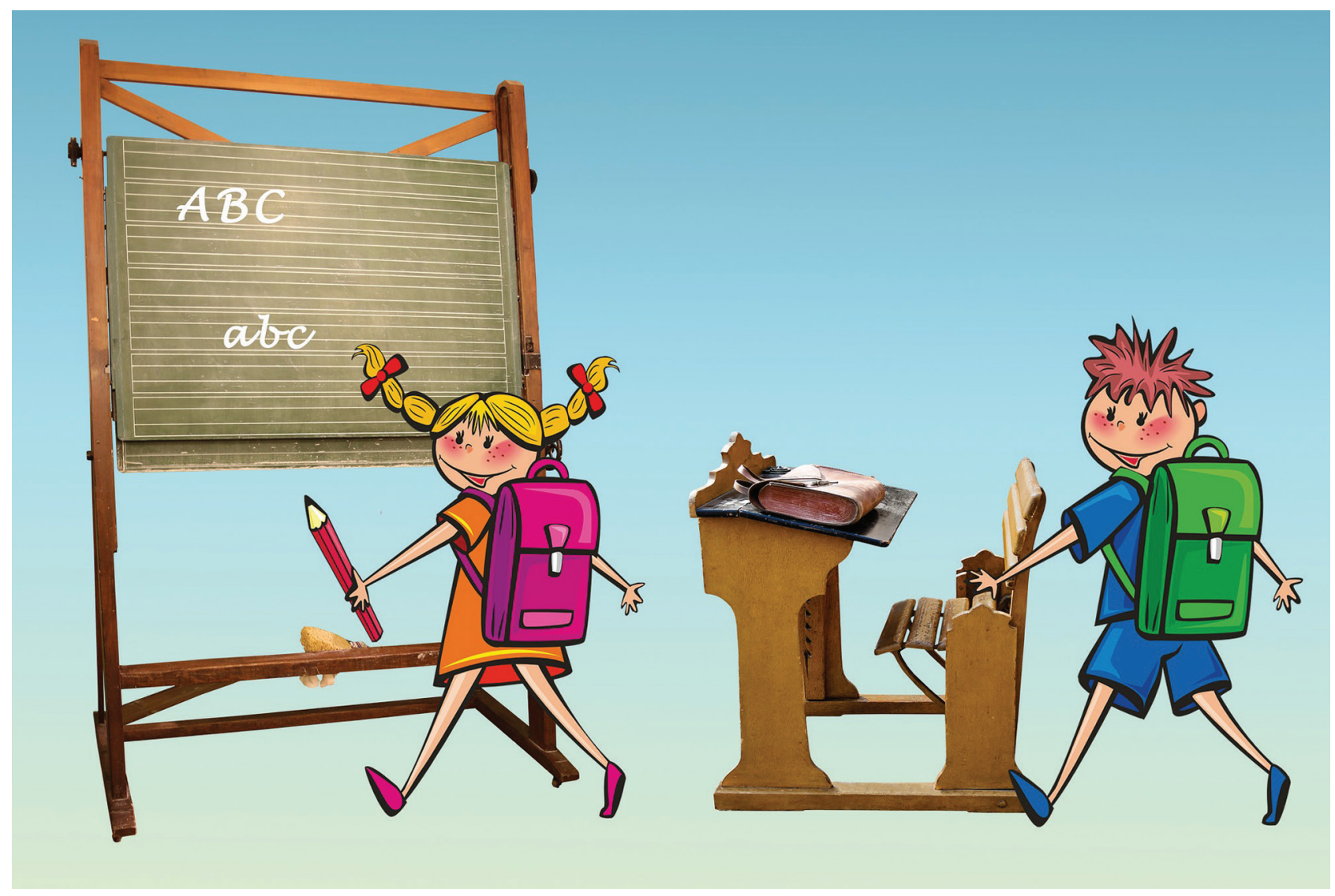

